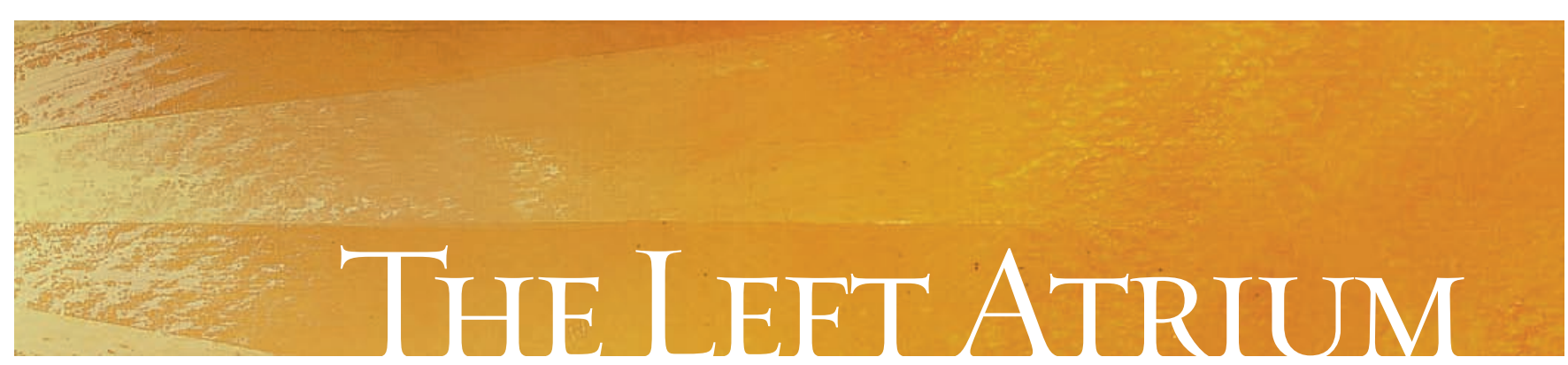

\title{
Annotations
}

\section{War: a crucible for advances in surgery}

Dr. Angus Campbell Derby (1914-2006) was only one year out of medical school (McGill '41) when he joined the Royal Canadian Army Medical Corps in 1942. In 1943, he was posted overseas, where he served as a physician in an Advance Surgical Centre (A.S.C.), treating and triaging wounded soldiers straight from the battlefield. The following is an excerpt from his self-published memoirs - Not Least in the Crusade: the Memoirs of a Military Surgeon. The memoirs recount his role as a field surgeon in WWII and the Korean war, as well as experiences as a peacetime surgeon in the Canadian Armed Forces. Below, Derby's keen interest in the history of surgical techniques and his respect for his mentors shines through his writing. - Editor's note

I $t$ was not until the turn of the 2oth century, with the formation of the British and Canadian Medical Corps, that military commanders reluctantly accepted, as part of the battle plan, medical units with fixed establishments. Military surgeons quickly discovered that war wounds had dire consequences for the soldier, and the more sophisticated the weapon, the more complicated the injury. Serious wounds in most cases led to death. If the soldier did survive the initial wound, he could then look forward, all too frequently, to infection, gangrene, secondary hemorrhage, amputation, and eventually death or permanent deformity or disability. Even at the turn of the 2oth century the treatment of infection and gangrene in war wounds remained an enigma.

At the outbreak of WWI, however,

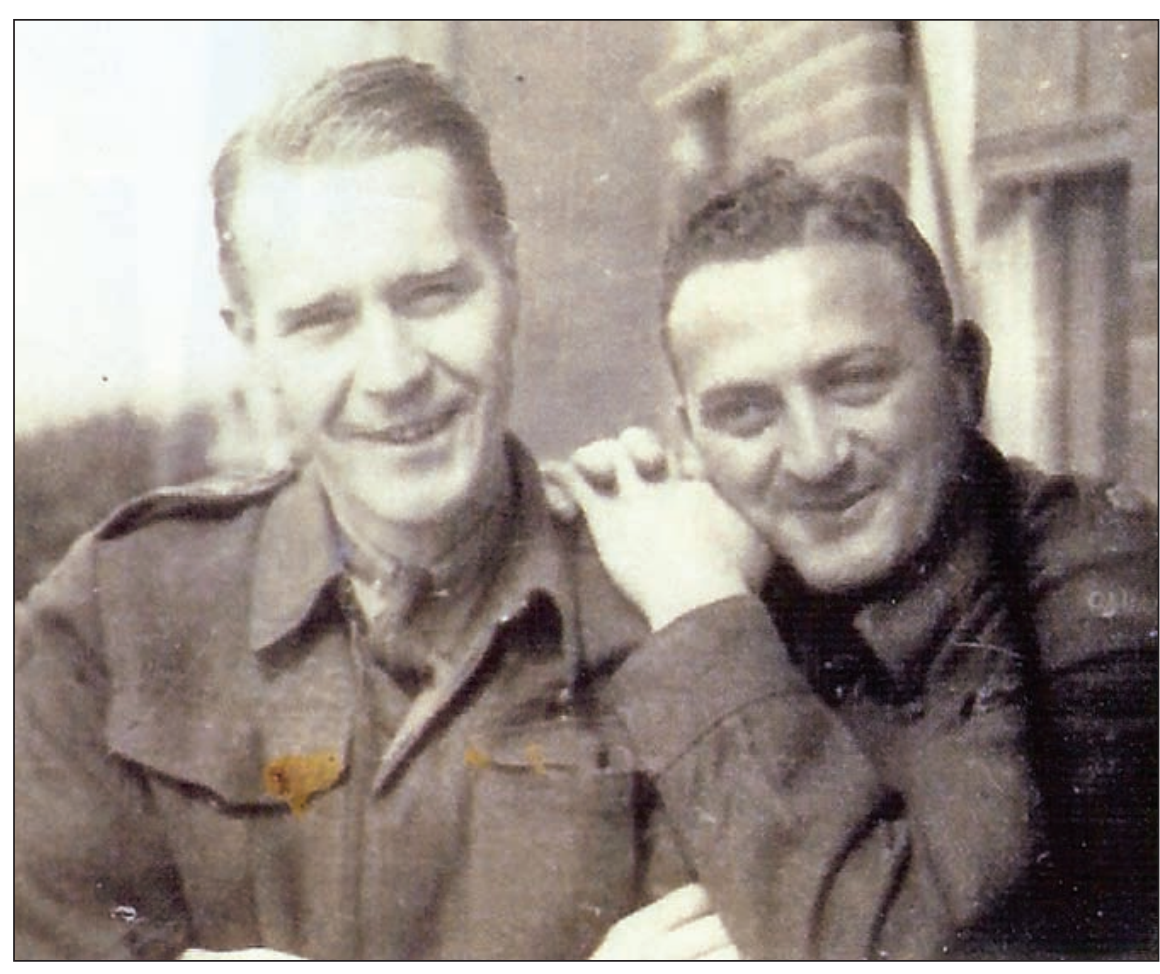

Author (Dr. Angus Campbell Derby) (left) and Dr. Lawrence "Rab" Rabson, Chief of Surgery (right)

the answers to the mysteries of the wounds of war seemed to have been solved. Pasteur had discovered bacteria and as a result, Lister advocated antisepsis. It is little wonder then that the surgeons set out for France with high hopes and gallons of antiseptics. Furthermore, new mobile forward medical units, the field ambulance and the casualty clearing station were to ensure adequate first aid and early evacuation of casualties.

Unfortunately, this is not how it worked out. Because of overwhelming numbers of wounded, surgery was often delayed up to 48 hours. The mor- tality, although improved, was anything but satisfactory. Infection and gangrene remained a problem. Amputation rates were unacceptably high, and soldiers continued to die of shock. That shock was a frequent complication of severe injury was well known, but no case or treatment was found until Henderson in 1908 showed that shock was due to reduction in blood volume, and this could be treated by replacing the lost fluid. Normal saline was advocated first; however, this could only be used on a limited basis in any one patient. Then the discovery of blood typing, just be- 
fore WWI, led to a unique opportunity for its use in war. Three Canadian surgeons, Robertson, Archibald and Guiou pioneered its use. Unfortunately blood had to be drawn on the spot and there were no storage facilities or any organization to supply large quantities of blood from civilian sources. At the end of this terrible war, there were 2 million battle casualties, 700 ooo deaths and a hospital mortality of over $12 \%$. The answer to the treatment of war wounds did not lie with antiseptic irrigation - the solution would have to await another conflict.

During the Spanish Civil War (1936-I939) units were introduced to collect blood from the civilian population and to store it under refrigerated conditions for use in the combat area. One of the first of these units was the Canadian Blood Transfusion Service of which Norman Bethune was a founding member. The success of the Spanish stimulated the British to organize a similar system for the second war: the centre was in Bristol. It grew to such an extent that eventually all commonwealth theatres, including the home front and the Middle East, were served. Only group O blood, the universal donor, was used. Refrigerated blood and its derivatives were flown to base transfusion units then taken in refrigerator trucks to the field transfusion units. We never ran out of blood - one day in Normandy our A.S.C. used 25 units. We also took penicillin to the continent with us, and it played a part in reducing infection. Its greatest value I believe was in cases that were already infected because of delay in evacuations for surgery.

More significant than penicillin in reducing hospital mortality was the advance made during the Spanish Civil War and reported by Professor J. Trueta of Madrid. In the first war, the medical corps optimistically had taken gallons of antiseptic to the continent, but it still hadn't solved the problem of infection and gangrene. Trueta had done forward surgery in this war, and realized that you couldn't just pour antiseptic into the wound. You had to remove the dead muscle as well. In 1940 he reported what should have been obvious namely that missiles produce damage, not only in the direction of flight, but also at the right angles. This produces damage to muscle and adjacent

\section{One thousand words}

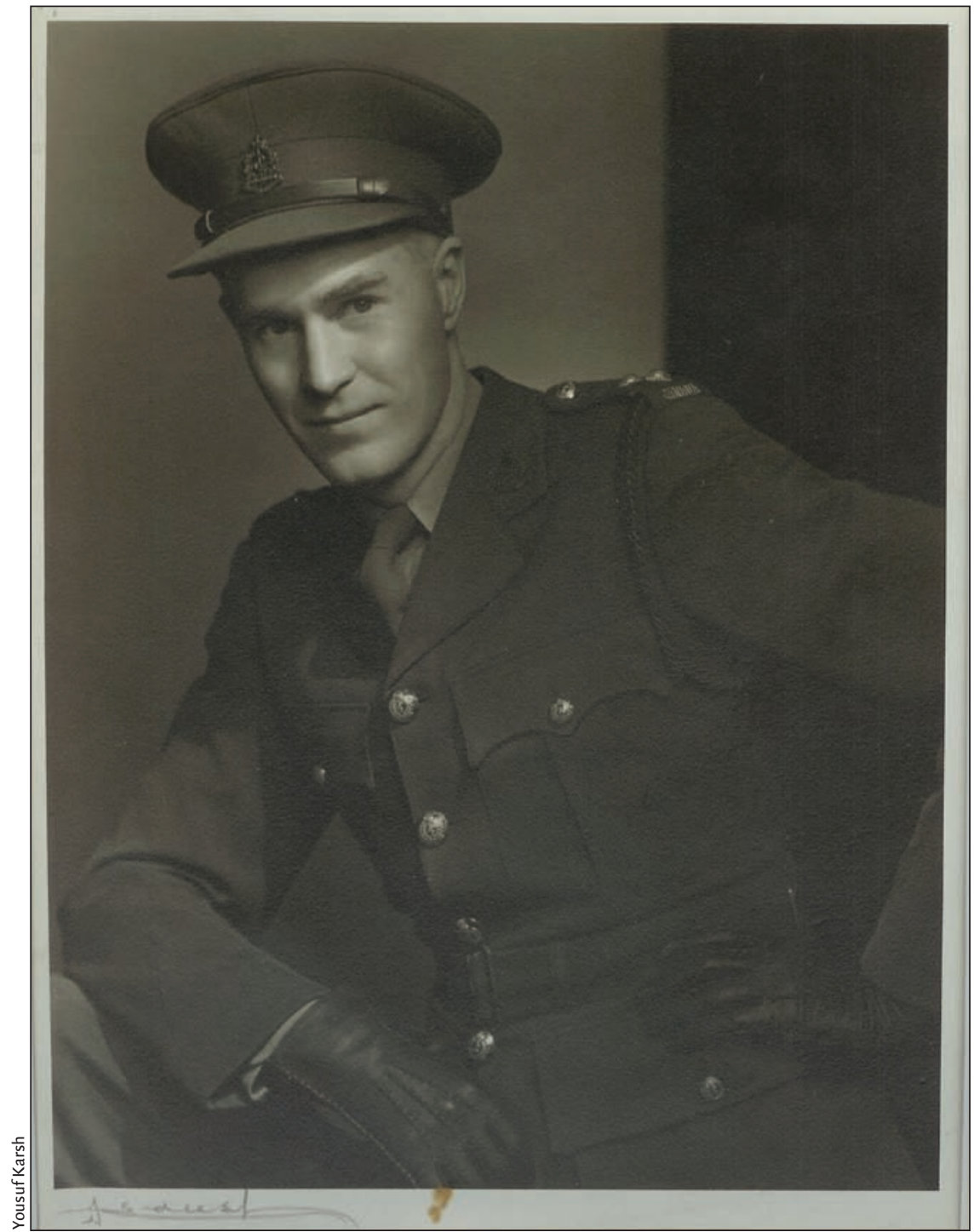

"My chief joy is to photograph the great in heart, in mind, and in spirit, whether they be famous or humble." - Yousuf Karsh.

In 1942, Dr. Angus Campbell Derby, a brand new physician and aspiring surgeon, joined the Canadian Armed Forces. Joining during World War II meant he would almost certainly go off to Europe, perhaps never to return. His family insisted that he have his photograph taken by a professional photographer, and it was - by Yousuf Karsh. With a studio located near the Canadian Parliament Buildings, Karsh (1908-2002) was just beginning to make his mark by photographing visiting dignitaries. Only months prior to photographing Derby, Karsh had photographed Winston Churchill, then Prime Minister of Great Britain. The Churchill image brought Karsh international attention and is claimed to be the most reproduced photographic portrait in history. Karsh is now recognized as one of the most talented portrait photographers of all time. How indicative of greatness, that Karsh brought the same care and talent to capturing the character of a young soldier, as he did to photographing Churchill. - Cathy Younger-Lewis, CMAJ 
ideal medium for bacterial growth. Trueta reported that the terrible infection rate of previous wars could be prevented by early débridement of all penetrating and perforating wounds, that is, the enlargement of the wound at the entrance and exit (if one existed). All the dead and devitalized muscle and other tissue were removed until the muscle bled, indicating it was clean and viable muscle. The wounds were then left open. Pressure dressing followed, and splints applied when indicated. In approximately 7 days, if the wound were clean, it was closed.

Prior to the invasion, along with a group of doctors, I went to London to hear Trueta speak about his findings. It was all very new, and I was enthralled with his solution to the problem of infection. After the lecture, Laurie Rabson, my Chief of Surgery, said in great excitement, "Of course. That's the way we are going to do it!"

Professor Trueta's work was enthu- siastically incorporated in the battle plan in the desert, Italy and Europe. The results were indeed rewarding. The answer to the infected wound and gangrene had arrived. The hospital mortality rate was reduced to $4.5 \%$ (3 times less than in WWI) with obvious reduction in morbidity. In our opinion, Trueta was a war surgeon hero.

- Excerpt from the memoir Not Least in the Crusade: the Memoirs of a Military Surgeon, 2005, Angus Campbell Derby

\section{Book review}

\section{The placebo effect deserves our time}

\author{
The placebo effect and health: combining \\ science \& compassionate care \\ W. Grant Thompson \\ Prometheus Books; 2005 \\ 350 pp \$23.00 ISBN 1-59102-275-4
}

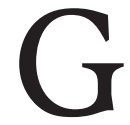
rant Thompson, a gastroenterologist, has written a reasoned, careful analysis of many aspects of current health systems and how they have evolved. $\mathrm{He}$ writes very clearly and logically.

Physicians, and particularly family doctors, must have the time and appropriate technology to practise what Thompson clearly feels is the backbone of medical care in our society. Rushed medicine without the ability to access proper informative medical documentation is deplored and deservedly so - unfortunately, we all acknowledge that this lack of time and technology is still usually the norm in Canadian medicine.

But why such an emphasis on "the placebo effect"? Thompson carefully defines, describes and details the role क्ष्ठ of placebo in research. Doctors' behaviours in themselves can be placebos and correspondingly "nocebos" or negative behaviour producers.

I wish that Thompson had written about how long the placebo response

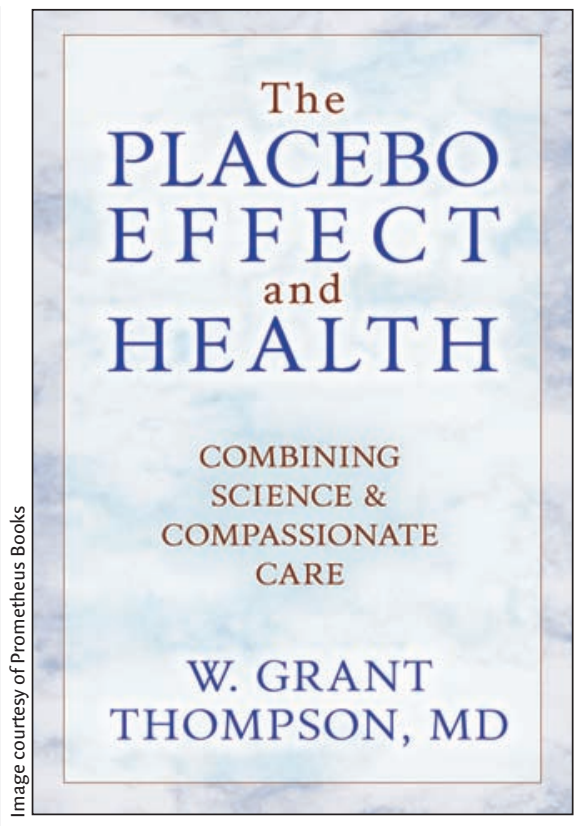

lasted in the various studies cited. This reviewer believes in the concept of placebo. I would like medical students, residents and doctors to think in greater detail about how their actions influence the therapeutic response in their patients: how what they are saying and the way they say it can influence a patient's understanding of their illness (e.g., irritable bowel syndrome, low-back pain or fibromyalgia). How eliciting specific psychological and social information can contribute to patients' improvement at a biochemical, physiological and ultimately clinical level.

Thompson's formula for successful medical intervention includes seeking well-founded evidence-based medicine and an optimum medical system of family physicians and specialists working in technical and respectful harmony. Another "bottom line" gleaned from reading this book is that physicians have to care. We have to feel that what's going on between our patients and us is meaningful, worthwhile and actually works. We have to recognize as well that when we develop that unique patient-doctor bond, what we say and how we say it can be therapeutic in many ways.

The placebo and nocebo concepts are fine. Physicians are being urged by Dr. Thompson to get into the trenches and fight for the right to practise medicine the way we know it should be, before some of the bureaucrats and medical technocrats take over. Important facts and concepts are offered in this book to propel this argument forward.

\section{Hillel M. Finestone}

Physiatrist

Associate Professor

University of Ottawa

Ottawa, Ont. 